DOI: https://doi.org/10.24127/ajpm.v10i3.3790

\title{
APA SAJA TIPE BERPIKIR PROBLEM-SOLVERS DALAM MEMECAHKAN MASALAH GEOMETRI ANALITIK?
}

\author{
Muhammad Noor Kholid ${ }^{*}$, Ahmad Zul Fakar², Annisa Swastika ${ }^{3}$, \\ Swasti Maharani $^{4}$ \\ ${ }^{1 *, 2,3}$ Pendidikan Matematika Universitas Muhammadiyah Surakarta, Surakarta. \\ ${ }^{4}$ Pendidikan Matematika Universitas PGRI Madiun, Madiun. \\ ${ }^{*}$ Corresponding author. Jl. Ahmad Yani Tromol Pos 1 Kartasura - Sukoharjo - Surakarta 57162 \\ E-mail: $\quad$ muhammad.kholid@ums.ac.id $^{\left.l^{*}\right)}$ \\ zul25fakar@gmail.com $^{2)}$ \\ annisa.swastika@ums.ac.id ${ }^{3)}$ \\ swasti.mathedu@unipma.ac.id ${ }^{4)}$
}

Received 07 June 2021; Received in revised form 12 September 2021; Accepted 25 September 2021

\begin{abstract}
Abstrak
Setiap problem-solver memiliki tipe yang berbeda. Adapun tipe berpikir digolongkan menjadi tipe berpikir konseptual, semi-konseptual, dan komputasional. Namun demikian belum ada penelitian terkait tipe berpikir dalam memecahkan masalah geometri analitik. Penelitian ini bertujuan untuk memaparkan apa saja tipe berpikir problem-solvers dalam memecahkan masalah geometri analitik. Penelitian merupakan penelitian kualitatif deskriptif dengan partisipan yaitu mahasiswa calon guru di Prodi Pendidikan Matematika FKIP Universitas Muhammadiyah Surakarta. Instrumen penelitian yang dipekerjakan yaitu masalah/tes geometri analitik, lembar observasi, dan pedoman wawancara. Instrumen divalidasi oleh beberapa ahli. Data diperoleh menggunakan metode tes, observasi, dan wawancara mendalam. Keabsahan data yang dipekerjakan yaitu triangulasi metode. Data dianalisis melalui tahap reduksi, penyajian, dan penarikan kesimpulan. Adapun penelitian menyimpulkan tipe berpikir konseptual, semikonseptual, dan komputasional. Ketiga tipe berpikir memiliki penciri utama dalam memecahkan masalah geometri analitik,
\end{abstract}

Kata kunci: Berpikir konseptual; berpikir semi-konseptual; berpikir komputasional; tipe berpikir; pemecahan masalah geometri analitik.

\begin{abstract}
Each problem-solver has different characteristics. The characteristics of thinking are classified into conceptual, semi-conceptual, and computational thinking characteristics. However, the thinking characteristics in solving analytical geometry is not known yet. The research aims to explain how the characteristics of thinking problem-solvers in solving the problem of analytical geometry. Research is descriptive qualitative research with participants, namely prospective teachers in the Mathematics Education Program FKIP University of Muhammadiyah Surakarta. The research instruments employed are analytical geometry problems/tests, observation sheets, and interview guidelines. Some experts validate the instrument. The data was obtained using a test, observation, and in-depth interview methods. The validity of the data employed is the triangulation method. The data is analyzed through the stages of reduction, presentation, and withdrawal of conclusions. The study concluded the characteristics of conceptual, semi conceptual, and computational thinking. The each thinking characteristics have their own main feature.
\end{abstract}

Keywords: Characteristics of thinking; computational thinking; conceptual thinking; semi-conceptual thinking; problem-solving of analytical geometry. 
DOI: https://doi.org/10.24127/ajpm.v10i3.3790

\section{PENDAHULUAN}

Filah (2017) mendefinisikan berpikir sebagai aktivitas yang dilakukan secara sadar untuk mengkaji suatu permasalahan yang dihadapinya sehingga dapat menyusun kesimpulan atau solusi yang tepat untuk permasalahan tersebut. Komariyah \& Laili (2018) menambahkan bahwa selama melakukan berpikir, individu perlu mengelola dan mentransformasi informasi yang dimiliki untuk memecahkan masalah. Individu dapat membangun dan mengembangkan pengetahuan melalui proses berpikir (Halpem, 2013). Setiap individu memiliki karakteristik ataupun level berpikir yang berbeda (Zhang et al., 2019).

Effendi \& Farlina (2017) menambahkan bahwa semakin baik kemampuan berpikir individu, semakin matang pula kesiapan individu dalam menghadapi berbagai situasi. Perkembangan ilmu pengetahuan dan tekonologi mengakibatkan kompleknya permasalahan yang perlu diselesaikan dengan melibatkan kemampuan berpikir yang logis, kritis, dan kreatif (Rahmatina et al., 2014). Perlu dilakukan upaya guna mengembangkan berpikir yang logis, kritis, dan kreatif seperti penerapan pemecahan masalah (Ngilawajan, 2013) sebab pemecahan masalah dapat menstimulasi individu sebagai problem-solver untuk melakukan eksplorasi, observasi, eksperimen, dan investigasi secara maksimal (Bernard et al., 2018). Harahap \& Surya (2017) dan Bernard et al. (2018) memaparkan bahwa melalui pemecahan masalah, problem-solver memiliki pengalaman dalam menyusun pengetahuan baru.

Problem-solver memiliki karakteristik berpikir yang berbeda dalam memecahkan masalah (Zuhri,
1998). Terdapat tiga karakteristik berpikir yaitu konseptual, semikonseptual, dan komputasional. Problem-solver dengan karakteristik berpikir konseptual cenderung memiliki proses berpikir dengan menggunakan konsep-konsep yang telah didapat pada pembelajaran sebelumnya. Hal ini menunjukkan bahwa mereka memiliki pemahaman yang baik pada materi dan konsep yang telah dipelajari. Sedangkan problem-solver dengan karakteristik berpikir semi konseptual memiliki kurangnya pemahaman yang kurang menyeluruh tentang konsep sehingga timbul dorongan untuk menyelesaikan permasalah dengan melibatkan antara konsep dan intuisi. Karakteristik ketiga yaitu berpikir komputasional dengan ciri-ciri problem-solver lebih cenderung pada intuisi, dan menyampingkan penggunaan konsep. Kondisi ini disebabkan karena mereka tidak memahami konsep-konsep yang ada sehingga lebih mengandalkan intuisi dalam memecahkan masalah.

$\begin{array}{ccc}\text { Beberapa } & \text { penelitian } & \text { terkait } \\ \text { karakteristik } & \text { berpikir } & \text { dalam }\end{array}$
memecahkan masalah telah dilakukan. Kusumo \& Suliani (2020) mengidentifikasi tipe berpikir problemsolver dalam memecahkan masalah matematika. Problem-solver dengan kemampuan matematis tinggi memiliki tipe berpikir konseptual karena menunjukkan seluruh indikator konseptual, sedangakan tipe berpikir untuk problem-solver berkemampuan matematis sedang dan rendah tidak dapat diidentifikasi karakteristik berpikirnya. Namun, penelitian Cahyo \& Setianingsih (2013) menyimpulkan bahwa karakteristik berpikir problemsolver dengan kemampuan matematis tinggi dan sedang tidak dapat diidentifikasi, melainkan problemsolver dengan kemampuan rendah 
memiliki tipe berpikir komputasional. Hasil penelitian yang berbeda juga ditunjukkan oleh Nafi'an (2016). Penelitian menyimpulkan problemsolver dengan kemampuan matematis tinggi cenderung memiliki tipe berpikir konseptual, problem-solver berkemampuan matematis sedang cenderung memiliki tipe berpiki semi konseptual, dan problem-solver berkemampuan matematis rendah memiliki tipe berpikir komputasional.

Penelitian karakteristik berpikir kaitannya dengan gaya kognitif field independent dan field dependent telah dilakukan oleh (Susandi \& Widyawati, 2017). Kedua penelitian menyimpulkan bahwa problem-solver dengan gaya kognitif field independent memiliki tipe berpikir konseptual, dan problem-solver dengan gaya kognitif field dependent memiliki tipe berpikir komputasional. Hal ini menunjukkan bahwa terdapat kaitan antara karakteristik berpikir dengan gaya kognitif.

Penelitian-penelitian tersebut berfokus pada konten persamaan linier, dan statistika dengan tipe soal cerita. Penelitian yang mengkaji karakteristik berpikir problem-solver dalam memecahkan masalah geometri analitik belum pernah dilakukan. Dalam pemecahan masalah geometri analitik problemsolver harus memecahkan masalah konten geometri namun dengan cara aljabar. Hal ini mengindikasikan adanya kemungkinan perbedaan karakteristik berpikir dalam memecahkan masalah geometri analitik.

Paparan tersebut menunjukkan bahwa belum terdapat penelitian terdahulu yang mengkaji tipe berpikir mahasiswa dalam memecahkan masalah geometri analitik beserta deskripsi perbedaannya. Penelitian terkait karakteristik berpikir dalam memecahkan masalah geometri analitik perlu dilakukan karena geometri analitik juga merupakan matakuliah yang wajib ditempuh oleh mahasiswa Prodi Pendidikan Matematika FKIP Universitas Muhammadiyah Surakarta. Hasil penelitian dapat dijadikan pedoman, tolak ukur, dan bahan refleksi mahasiswa sebagai calon guru dalam mengidentifikasi karakteristik berpikirnya sehingga dapat dilakukan upayaupaya defragmentasi. Defragmentasi merupakan upaya memperbaiki struktur berpikir problem-solver dalam memecahkan masalah (Wibawa, 2019). Apabila tidak dilakukan akibatnya tipe berpikir mahasiswa sebagai calon guru tidak diketahui, sehingga mereka tidak memiliki bahan refleksi untuk melakukan upaya perbaikan kualitas pemecahan masalah.

Penelitian ini bertujuan untuk mengetahui apa saja tipe berpikir mahasiswa calon guru matematika dalam memecahkan masalah geometri analitik beserta deskripsinya. Ketika tipe berpikir mahasiswa calon guru sudah diketahui, maka mereka dapat melakukan upaya perbaikan kualitas pemecahan masalahnya untuk meningkatkan hasil belajarnya.

\section{METODE PENELITIAN}

\section{Jenis Penelitian}

Penelitian merupakan penelitian kualitatif deskriptif yaitu penelitian yang memaparkan fakta, gejala, dan fenomena tanpa adanya manipulasi (Sagala et al., 2019). Data yang dideskripsikan yaitu karakteristik berpikir mahasiswa calon guru matematika dalam memecahkan masalah geometri analitik.

\section{Partisipan}

Konten geometri analitik merupakan mata kuliah yang wajib ditempuh oleh mahasiswa semester dua 
DOI: https://doi.org/10.24127/ajpm.v10i3.3790

Prodi Pendidikan Matematika FKIP Universitas Muhammadiyah Surakarta. Pada tahun akademik 2020/2021 terdapat 167 mahasiswa yang menempuh mata kuliah geometri analitik. Penentuan subjek menggunakan metode purposive sampling (Putranta \& Jumadi, 2019) sehingga diperoleh 37 mahasiswa. Adapun distribusi karakteristik berpikir mahasiswa yaitu 10 orang mahasiswa memiliki karakteristik berpikir konseptual, 12 orang mahasiswa memiliki karakteristik berpikir semi-konseptual, dan 15 orang mahasiswa memiliki karakteristik berpikir komputasional.

\section{Instrumen}

Instrumen yang dipekerjakan pada penelitian yaitu: 1) masalah geometri analitik, 2) lembar observasi, dan 3) pedoman wawancara semi terstruktur. Ketiga instrumen telah divalidasi oleh tiga orang validator yang ahli dibidang geometri analitik, penelitian kualitatif Pendidikan matematika, dan mathematical thinking skills.

\section{Metode Pengumpulan Data}

Data dikumpulkan dengan metode tes, observasi, dan wawancara mendalam. Subjek diminta memecahkan masalah geometri analitik (Gambar 1) dengan metode think-aloud. Metode ini diterapkan dengan meminta subjek memecahkan masalah sambal berbicara untuk melaporkan alur berpikir dalam memecahkan masalah (Eccles \& Arsal, 2017).

\begin{tabular}{|l|}
\hline \multicolumn{1}{|c|}{ MASALAH GEOMETRI ANALITIK } \\
\hline Tentukan titik tembus garis g yang melalui $(-2,-3,1)$ dan $(3,4,-5)$ \\
dengan bidang $V: 2 x+y+z-7=0$ \\
\hline
\end{tabular}

Gambar 1. Masalah geometri analitik

Pengumpulan data dilakukan melalui metode observasi dan merekam proses pemecahan masalah dengan alat perekam audio-visual. Wawancara mendalam juga direkam untuk menggali karakteristik berpikir subjek. Triangulasi metode dilakukan untuk menjamin keabsahan data tes (lembar jawab dan transkrip think-aloud), hasil observasi, dan hasil wawancara (transkrip wawancara).

\section{Analisis Data}

Data dianalisis melalui tiga tahap yaitu reduksi, penyajian, dan penarikan kesimpulan (Miles et al., 2014). Tahap reduksi dilakukan untuk memilih dan memilah data-data yang menunjang tercapainya tujuan penelitian. Data disajikan berdasarkan karakteristik berpikir subjek. Pada tahap terakhir yaitu menyimpulkan hasil penelitian untuk menjawab masalah penelitian.

\section{HASIL DAN PEMBAHASAN}

Pada bagian ini dipaparkan data penelitian dari tiga subjek yang terdiri dari subjek dengan karakteristik berpikir konseptual (berikutnya disebut subjek S-1), subjek dengan karakteristik berpikir semikonseptual (berikutnya disebut subjek S-2), subjek dengan karakteristik berpikir komputasional (berikutnya disebut subjek S-3). Data tersebut dipilih sebab data merepresentasikan keseluruhan data dari masing- 
DOI: https://doi.org/10.24127/ajpm.v10i3.3790

masing karakteristik berpikir. Berikutnya hasil temuan akan dibahas melalui komparasi dengan hasil temuan penelitian-penelitian sebelumnya.

\section{Paparan data Subjek S-1}

S-1 mampu mengidentifikasi dan menuliskan data-data yang terdapat pada soal dengan bahasanya sendiri. S-1 terlihat menuliskan titik $A$, titik $B$, dan juga persamaan bidang $V$. S-1 mampu untuk menunjukkan inti pertanyaan atau permasalahan pada soal dengan bahasanya sendiri dengan menuliskan inti permasalahan yakni mencari titik tembus $T$.

Dalam memecahkan masalah S-1 selalu menjawab dengan format menuliskan apa yang diketahui, ditanya, dan dijawab. Hal ini diperkuat dengan jawaban S-1 pada sesi wawancara.

$P \quad$ : "Ini untuk format penulisanmu selalu seperti itu? Ada diketahuinya, ditanya, dan dijawab?"

S-1 : "Iya, setiap ada soal ketika saya menjawab saya tuliskan apa yang diketahui, ditanya, dijawab, dan saya beri kesimpulan"

S-1 membuat perencanaan dalam memecahkan persoalan. Hal ini dijelaskan oleh S-1 dalam wawancaranya bahwa S-1 setelah ia membaca soal yang diberikan, S-1 memiliki bayangan/ gambaran didalam pikirannya tentang langkah-langkah yang nanti akan dilakukan. S-1 juga membuat coretan-coretan atau perhitungan sebelum menjawab dilembar jawab. Sebagai contoh ketika menghitung determinan matriks, S-1 hanya menuliskan tentang bentuk persamaan dalam matriksnya, untuk perhitungan dan penyempurnaannya dilakukan dilembar jawab langsung. Cara ini dipilih oleh S-1 karena untuk efisiensi waktu. S-1 berpendapat bahwa semua jawaban dituliskan di lembar coretan terlebih dahulu maka seperti kerja dua kali sehingga S-1 hanya menuliskan sketsa perhitungannya dan menyempurnakan dalam lembar jawab. Gambar 2 merupakan lembar jawab S-1 dalam memecahkan masalah.
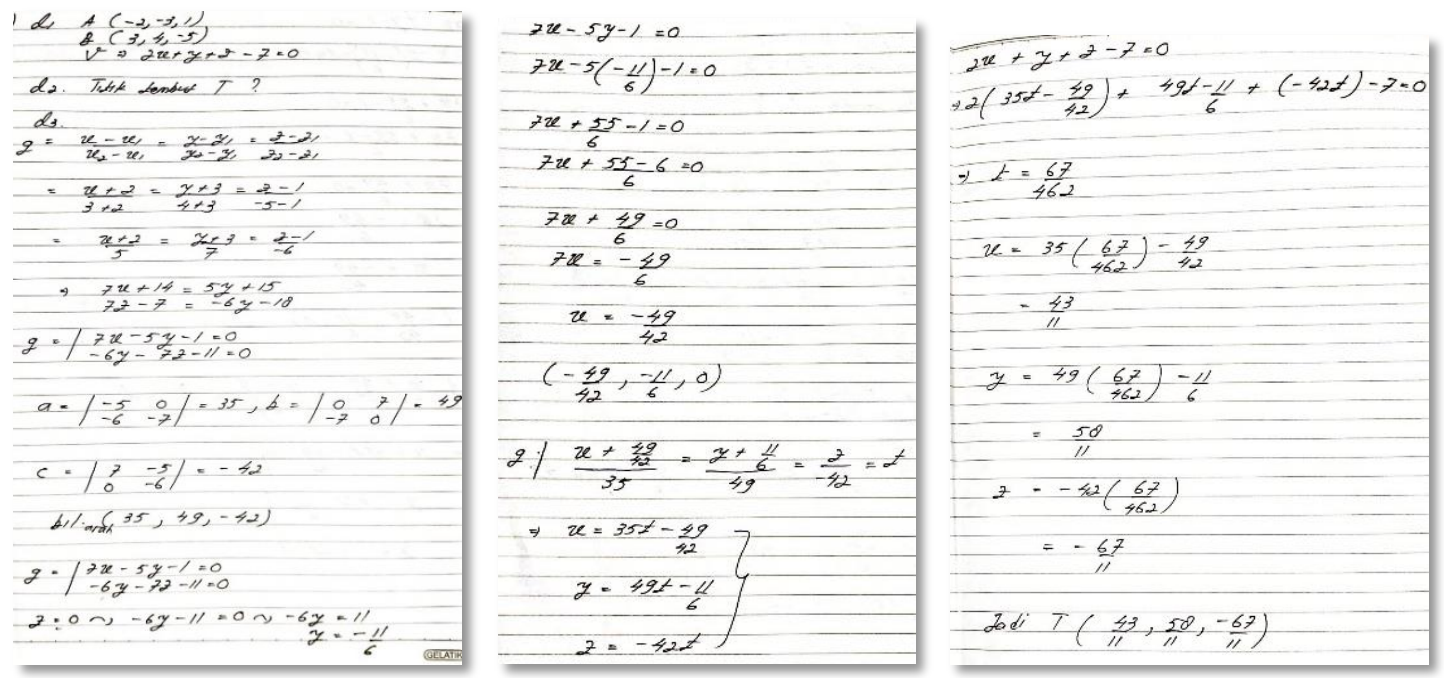

Gambar 2. Lembar jawab S-1

Dalam menjawab soal, S-1 menjawab secara runtut sesuai dengan konsep yang telah ada. S-1 mencari terlebih dahulu persamaan garis $g$ 
dengan mensubstitusikan titik kedalam rumus yang telah ditulis, melakukan komputasi, membuat perasamaan parameter, substitusi kedalam persamaan bidang, hingga mendapatkan titik tembus garis terhadap bidang, dan tidak lupa memberikan kesimpulan dibagian akhir jawaban.

Jawaban yang diberikan oleh S-1 tersebut benar. Pada kasus jawaban yang salah, S-1 menjelaskan bahwa S-1 akan bertanya dan melihat jawaban teman yang benar dan melakukan analisa langkah dan perhitungan untuk menemukan kesalahan yang dilakukan.

S-1 : "Misal jawaban saya dan jawaban teman berbeda. Kemudian saya meneliti pembahasannya dari awal sampai akhir kok jawaban saya bisa gini, kok jawaban teman saya bisa gini. Sehingga saya teliti kembali supaya jawaban dengan teman itu sama."

\section{Paparan data Subjek S-2}

S-2 cukup dapat mengidentifikasi data-data dan inti permasalahan yang terdapat pada soal. Hal ini dapat ditunjukkan dalam lembar jawaban S-2 dengan gaya penulisannya, S-2 menuliskan data-data yang terdapat pada soal. Meskipun S-2 hanya menyisipkan data tersebut pada bagian atas lembar jawaban dengan menuliskan titik $(-2,-2,1),(3,4,-5)$, dan bidang $V$ : $2 x+y+z-7=0$.
Hasil wawancara juga memperkuat bahwa S-2 cukup dapat mengidentifikasi data-data dan inti permasalahan yang terdapat pada soal,

$P \quad$ : "Ini kalau kamu mengerjakan soal, tugas, tes atau uas, langsung seperti ini?

S-2 : "Karena ini beda situasi, jadi saya itu langsung saja. Biasanya saya pakai diketahui, ditanya, dijawab gitu Mas"

Dalam menjawab permasalahan, S-2 selalu menuliskan rumus secara umum terlebih dahulu. Terlihat bahwa S-2 rumus untuk mencari persamaan garis dan kemudian diparameter dengan t. Skema jawaban S-2 juga konsisten dengan menyebutkan data yang ada pada soal seperti titik, persamaan, dll, meskipun data yang disebutkan hanya seperti coret-coretan data, tidak ditulis secara rapi dengan indikator diketahui, diatanya dan dijawab. Kemudian menuliskan rumus secara umum seperti rumus untuk mencari bidang yang melalui tiga titik, rumus jarak titik dengan bidang dan rumus bidang sejajar. Melakukan substitusi dan komputasi. S-2 tidak selalui memberikan kesimpulan dengan menulis ulang jawaban atau hasil akhir dari komputasi yang telah dilakukan. Gambar 3 merupakan lembar jawab S-2 dalam memecahkan masalah.

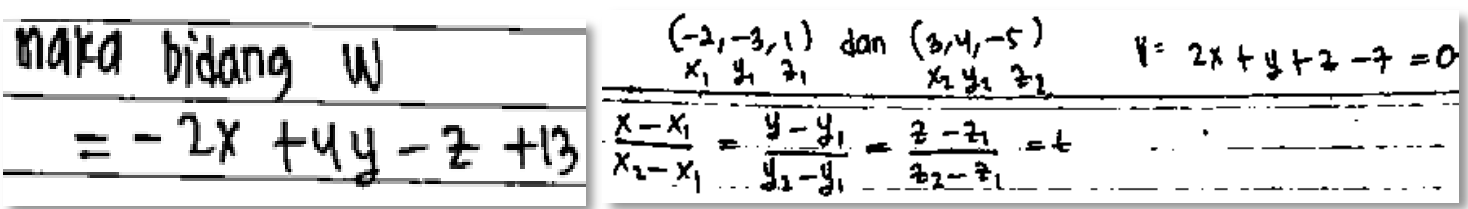

Gambar 3. Lembar jawab S-2

Jawaban S-2 tidak seluruhnya benar, karena S-2 kesalahan dalam substitusi titik kedalam rumus dengan kesalahan pada tanda yang seharusnya negatif tetapi ditulis positif. Namun S-2 mengatakan bahwa S-2 dapat 
DOI: https://doi.org/10.24127/ajpm.v10i3.3790

membenarkan jika terjadi kesalahan seperti ini.

\section{Paparan data Subjek S-3}

S-3 tidak dapat mengidentifikasi data pada soal karena pada lembar jawaban S-3 tidak menuliskan data-data apapun. Sama halnya dalam mengidentifikasi inti permasalahan, S-3 tidak dapat mengidentifikasi permasalahan yang disajikan dikarenakan S-3 tidak menuliskan inti permasalahan yang dihadapi dilembar jawaban. S-3 mengatakan bahwa ia lupa namun S-3 juga mencoba untuk mengingat langkah-langkah penyele- saian namun tidak tahu bagaimana cara mengerjakannya.

S-3 juga tidak dapat menyusun rencana dan pemecahana masalah secara runtut. Hal ini dikarenakan S-3 tidak ingat akan konsep dan rumus yang digunakan. Dalam lembar jawab yang diberikan oleh S-3, terlihat S-3 tidak dapat memecahkan permasalahan yang dihadapi. Terlihat S-3 kebingungan dan penuh keragu-raguan dalam memecahkan masalah dikarenakan lupa rumus dan lupa konsep. Gambar 4 merupakan lembar jawab S-3 dalam memecahkan masalah.

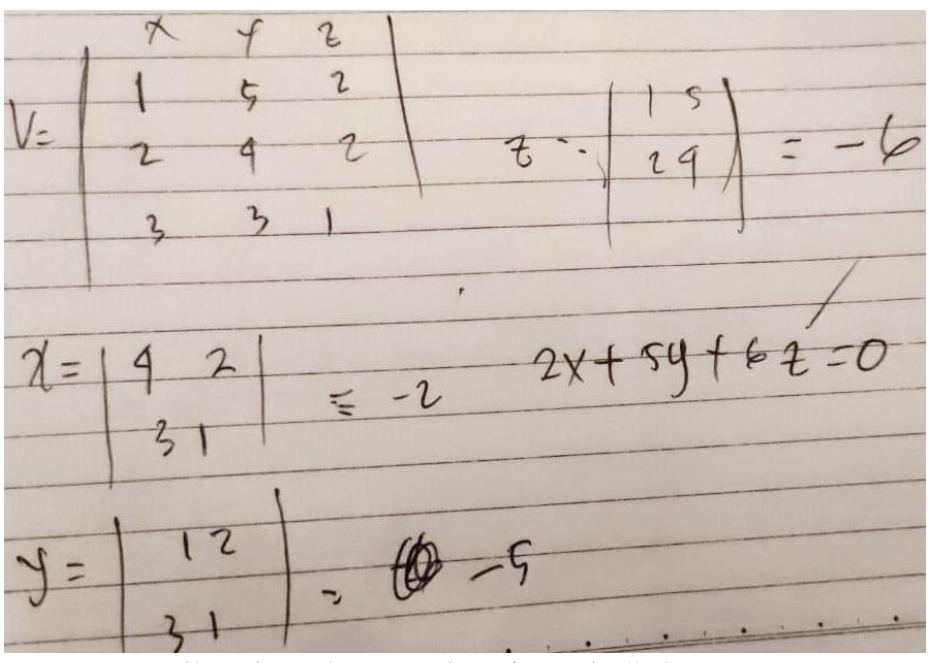

Gambar 4. Lembar jawab S-3

S-3 tidak dapat memecahkan permasalahan yang disajikan, alasan utama lupa rumus dan juga lupa konsep menjadikan S-3 ragu-ragu dan semakin bingung dalam memecahkan permasalahan. S-3 juga tidak dapat memperbaiki jawaban dikarenakan kesalahan yang dihadapi oleh S-3 bukanlah kesalahan dalam komputasi melainkan kesalahan dalam konsep dikarenakan S-3 lupa rumus dan juga konsep hal ini mengharuskan S-3 untuk mengingat semua rumus dan memahami semua konsep yang dubutuhkan kembali jika S-3 ingin dapat memperbaiki jawabannya.

\section{Pembahasan}

Tipe berpikir konseptual merupakan tipe berpikir dimana seseorang mampu memecahkan suatu permasalahan sesuai dengan konsep dan pengetahuan yang telah dimiliki (Kusumo \& Suliani, 2020; Zuhri, 1998). Subjek dengan tipe berpikir ini akan mampu untuk memecahkan permasalahan dengan terstruktur dan dengan jawaban yang benar sebagaimana termuat dalam indikator 
tipe berpikir. Penelitian ini sejalan dengan penelitian yang dilakukan oleh Handayani et al. (2020), Nafi'an (2016), dan Harso (2013). Namun tidak menutup kemungkinan tingkat kemampuan yang lain juga memiliki tipe ini. Pada penelitian ini, tipe berpikir konseptual ini dimiliki oleh S-1.

Tipe berpikir semi-konseptual adalah tipe berpikir yang cenderung memecahkan permasalahan sesuai dengan konsep dan pengetahuan yang dimiliki, namun mungkin karena pemahaman yang belum seluruhnya lengkap sehingga terdapat penyelesaian yang bercampur dengan intuisi (Kusumo \& Suliani, 2020; Zuhri, 1998). Subjek dengan tipe berpikir ini cukup mampu untuk memecahkan permasalahan dan mungkin muncul beberapa kesalahan komputasi atau penulisan, namun juga cukup mampu untuk memperbaikinya. Penelitian ini sejalan dengan hasil penelitian yang dilakukan oleh Cahyo \& Setianingsih (2013) dan Harso (2013). Namun tidak menutup kemungkinan tingkat kemampuan yang lain juga memiliki tipe ini. Pada penelitian ini, tipe berpikir konseptual ini dimiliki oleh S-2.

Tipe berpikir komputasional adalah tipe berpikir dimana seseorang cenderung menggunakan intuisi dalam memecahkan permasalahan tanpa menggunakan konsep-konsep yang ada (Kusumo \& Suliani, 2020; Zuhri, 1998). Subjek dengan tipe berpikir ini tidak mampu untuk memecahkan permasalahan dan memungkinkan untuk tanpa menggunakan konsep-konsep yang ada. Penelitian ini sejalan dengan hasil penelitian yang dilakukan oleh Handayani et al. (2020), Harso (2013) dan Nafi'an (2016). Namun tidak menutup kemungkinan tingkat kemampuan yang lain juga memiliki tipe ini. Pada penelitian ini, tipe berpikir konseptual ini dimiliki oleh S-3.

Hasil penelitian dapat dijadikan sebagai pedoman teori untuk penelitian berikutnya terkait tipe berpikir. Hasil penelitian dapat digunakan oleh dosen dalam memilih dan menerapkan strategi atau model perkuliahan yang sesuai dengan tipe berpikir mahasiswa.

\section{KESIMPULAN DAN SARAN}

Terdapat tiga tipe berpikir mahasiswa dalam memecahkan masalah geometri analitik yaitu konseptual, semi-konseptual, dan komputasional. Perbedaan ketiga berpikir tersebut disajikan sebagai berikut.

Mahasiswa dengan tipe berpikir konseptual mampu untuk mengidentifikasi data, mampu menunjukkan inti permasalahan yang ada, mampu menyusun dan menunjukkan penyelesaian, serta mampu memperbaiki jawaban. Berikutnya, siswa dengan tipe berpikir semi konseptual cukup mampu untuk mengidentifikasi data, cukup mampu menunjukkan inti dari permasalahan yang ada, cukup mampu menyusun dan menunjukkan penyelesaian, dan cukup mampu memperbaiki jawaban. Sedangkan siswa dengan tipe berpikir komputasional tidak mampu mengidentifikasi data, tidak mampu menunjukkan inti permasalahan, tidak mampu menyusun dan menunjukkan penyelesaian, dan tidak mampu memperbaiki jawaban.

Penelitian berfokus pada tipe berpikir konseptual, semi-konseptual, dan komputasional. Penelitian berikutnya dapat berfokus pada penemuan indikator pada masing-masing tipe berpikir sebagai penciri utama dalam mengkategorisasikan tipe berpikir mahasiswa. Ketiga tipe berpikir ditemukan pada pemecahan masalah geometri analitik. Penelitian berikutnya 
dapat menemukan tipe berpikir baru dalam memecahkan masalah matematis konten lainnya, missal kalkulus, statistika, dan aljabar.

\section{UCAPAN TERIMA KASIH}

Peneliti berterimakasih kepada Universitas Muhammadiyah Surakarta (UMS) yang telah mendanai penelitian ini melalui skema Hibah Integrasi Tridharma (HIT). Ucapan terimakasih juga kami tujukan kepada seluruh partisipan yang telah bersedia menjadi subjek penelitian.

\section{DAFTAR PUSTAKA}

Bernard, M., Nurmala, N., Mariam, S., \& Rustyani, N. (2018). Analisis Kemampuan Pemecahan Masalah Matematis Siswa SMP Kelas IX Pada Materi Bangun Datar. SJME (Supremum Journal of Mathematics Education), 2(2), 77-83.

https://doi.org/10.26877/jipmat.v3 i2.2700

Cahyo, A. N., \& Setianingsih, R. (2013). Tipe Berpikir Siswa dalam Memecahkan Masalah pada Materi Sistem Persamaanlinear Dua Variabel di Kelas VIII SMPN 1 Pacet. MATHEdunesa, 2(3), 18.

https://jurnalmahasiswa.unesa.ac.i d/index.php/mathedunesa/article/d ownload/3875/6421

Eccles, D. W., \& Arsal, G. (2017). The Think Aloud Method: What is It and How Do I Use It? Qualitative Research in Sport, Exercise and Health, 9(4), 514-531. https://doi.org/10.1080/2159676X .2017 .1331501

Effendi, K. N. S., \& Farlina, E. (2017). Kemampuan Berpikir Kreatif Siswa SMP kelas VII dalam Penyelesaian Masalah Statistika.
Jurnal Analisa, 3(2), 130-137. https://doi.org/https://doi.org/10.1 5575/ja.v3i2.2013

Filah, A. N. (2017). Analisis Kemampuan Berpikir Kritis Siswa dalam Menyelesaikan Soal Generalisasi Deret. Universitas Jember.

Halpem, D. F. (2013). Thought and Knowledge: An Introduction to Critical Thinking. Psychology Press.

Handayani, U. F., Sa'Dijah, C., Sisworo, Sa'Diyah, M., \& Anwar, L. (2020). Mathematical creative thinking skill of middle-ability students in solving contextual problems. AIP Conference Proceedings, 2215(April), 060007-1-060007-7.

https://doi.org/10.1063/5.0000645

Harahap, E. R., \& Surya, E. (2017). Kemampuan Pemecahan Masalah Matematis Siswa Kelas VII Dalam Menyelesaikan Persamaan Linier Satu Variabel. Prosiding Seminar Nasional Matematika Universitas Negeri Medan, 258279.

Harso, Y. Y. (2013). Tipe Berpikir Siswa SMPN 6 Surabaya dalam Memecahkan Masalah Berbentuk Cerita Persamaan Linear Satu Variabel. MATHEdunesa, 2(1), 18.

Komariyah, S., \& Laili, A. F. N. (2018). Pengaruh Kemampuan Berpikir Kritis terhadap Hasil Belajar Matematika. Jurnal Penelitian Pendidikan Dan Pengajaran Matematika, 4(2), 55-60. https://doi.org/https://doi.org/10.3 7058/jp3m.v4i2.523

Kusumo, M. H., \& Suliani, M. (2020). Identifikasi Tipe Berpikir Peserta Didik dalam Memecahkan Masalah Matematika. 
DOI: https://doi.org/10.24127/ajpm.v10i3.3790

MANDALIKA Mathematics and Educations Journal, 2(2), 76-84. https://doi.org/http://dx.doi.org/10 .29303/jm.v2i2.1752

Miles, M. B., Huberman, A. M., \& Saldana, J. (2014). Qualitative Data Analysis. Sage.

Nafi'an, M. I. (2016). Analisis Berpikir Konseptual, Semikonseptual Dan Komputasional Siswa Sd Dalam Menyelesaikan Soal Cerita. JP2M (Jurnal Pendidikan Dan Pembelajaran Matematika), 2(2), 72-77.

https://doi.org/https://doi.org/10.2 9100/jp2m.v2i2.208

Ngilawajan, D. A. (2013). Proses Berpikir Siswa SMK Dalam Memecahkan Masalah Matematika ditinjau dari Gaya Kognitif Field Independent dan Field Dependent. Pedagogia, 2(1), 71-83. https://doi.org/http://doi.org/10.21 070/pedagogia.v2i1.48

Putranta, H., \& Jumadi. (2019). Physics Teacher Efforts of Islamic High School in Yogyakarta to Minimize Students' Anxiety When Facing The Assessment of Physics Learning Outcomes. Journal for the Education of Gifted Young Scientists, 7(2), 119-136.

https://doi.org/10.17478/JEGYS.5 52091

Rahmatina, S., Sumarmo, U., \& Johar, R. (2014). Tingkat Berpikir Kreatif Siswa dalam Menyelesaikan Masalah Matematika Berdasarkan Gaya Kognitif Reflektif dan Impulsif. Jurnal Didaktik Matematika, 1(1), 62-70.

https://doi.org/10.24815/jdm.v1i1. 1242
Sagala, R., Nuangchalerm, P., Saregar, A., \& El Islami, R. A. Z. (2019). Environment-friendly education as a solution to against global warming: A case study at Sekolah Alam Lampung, Indonesia. Journal for the Education of Gifted Young Scientists, 7(2), 8597. https://doi.org/10.17478/jegys.565 454

Susandi, A. D., \& Widyawati, S. (2017). Proses Berpikir dalam Memecahkan Masalah Logika Matematika Ditinjau dari Gaya Kognitif Field Independent dan Field Dependent. NUMERICAL (Jurnal Matematika Dan Pendidikan Matematika), 1(1), 45-52. https://doi.org/https://doi.org/10.2 5217/numerical.v1i1.122

Wibawa, K. A. (2019). Fragmentation of the Thinking Structure of Translation in Solving Mathematical Modelling Problems. Southeast Asian Mathematics Education Journal, 9(1), 25-36.

Zhang, X. H., Kubota, K., Kubota, M., \& Li, K. (2019). Teacher's Developmental Stages of Exploring Thinking Tools in a Blended Learning Environment. International Conference on Blended Learning, 186-202. https://doi.org/https://doi.org/10.1 007/978-3-030-21562-0_16

Zuhri, D. (1998). Proses Berpikir Peserta didik Kelas II SMP Negeri 16 Pekanbaru dalam Menyelesaikan Soal-Soal Perbandingan Senilai dan Perbandingan Berbalik Nilai. Universitas Negeri Surabaya. 